\title{
EFEKTIVITAS PEMBELAJARAN BIOLOGI PADA MASA PANDEMI COVID-19 DI MADRASAH NEGERI MEDAN
}

\author{
Ifrah Syahmina ${ }^{*}$, Indayana Febriani Tanjung ${ }^{1}$, Rohani 1 \\ ${ }^{1}$ Universitas Islam Negeri Sumatera Utara \\ *ifrahsyahmina668@gmail.com
}

\begin{abstract}
ABSTRAK
Penelitian ini bertujuan untuk mengetahui faktor pendukung dan penghambat serta efektivitas pembelajaran biologi pada masa pandemi COVID-19 di MAN 1 Medan. Jenis penelitian ini merupakan deskriptif kualitatif. Teknik pengumpulan data dilakukan dengan wawancara, kuesioner, observasi dan dokumentasi. Analisis data yang digunakan pada penelitian ini adalah pengumpulan data, reduksi data, dan penyajian data. Hasil penelitian ini menunjukkan bahwa faktor penghambat pembelajaran dari rumah pada mata pelajaran biologi adalah jaringan internet, ketidakhadiran siswa saat daring, kondisi ekonomi siswa, dan kepemilikian gadget ataupun laptop. Adapun faktor yang mendukung adalah teknologi, tempat belajar sesuai dengan protokol kesehatan COVID-19, sumber belajar, media belajar yang memadai, rancangan pelaksanaan pembelajaran daring yang dirancang oleh guru, sikap antusias siswa dalam menuntut ilmu, dan sarana prasarana yang memadai. Kesimpulannya bahwa pelaksanaan pembelajaran dari rumah pada mata pelajaran biologi yang dilakukan di Madrasah Aliyah Negeri 1 Medan berjalan dengan efektif sesuai dengan aturan pemerintah melalui Surat Edaran No.15 Tahun 2020.
\end{abstract}

Kata Kunci: Efektivitas Belajar, Pembelajaran dari Rumah, Pandemi COVID-19

\begin{abstract}
This study aims to determine the supporting and inhibiting factors and the effectiveness of learning biology during the COVID-19 pandemic at MAN 1 Medan. This type of research is descriptive qualitative. The data collection technique is done by interview, questionnaire, observation and documentation. Data analysis used in this research is data collection, data reduction, and data presentation. The results of this study indicate that the inhibiting factors for learning from home in biology are the internet network, student absence online, the economic condition of the students, and the possession of a gadget or laptop. The supporting factors are technology, a place to study in accordance with the COVID-19 health protocol, adequate learning resources and learning media, the online learning implementation design designed by the teacher, the enthusiastic attitude of students in studying, and adequate infrastructure. The conclusion is that the implementation of learning from home in biology subjects carried out at Madrasah Aliyah Negeri 1 Medan runs effectively in accordance with government regulations through Circular No.15 of 2020.
\end{abstract}

Keywords: Effectiveness of Learning, Learning Biology from Home, COVID-19 Pandemic

\section{PENDAHULUAN}

Pendidikan

merupakan

proses

pemberdayaan dan pembudayaan peserta didik dalam pelaksanaan proses pembelajaran yang berlangsung selamanya (Usiono, 2014). Pada kegiatan pembelajaran yang dilakukan di sekolah terjadi learning process atau proses belajar yang melibatkan guru dan peserta didik dalam pelaksana proses belajar (Rohani, 2019).
Namun, terhitung Maret 2020 organisasi kesehatan dunia (WHO) menetapkan Corona Virus Disease (COVID-19) sebagai pandemi yang telah melanda lebih dari 200 negara di dunia. Corona virus adalah suatu kelompok virus yang dapat menyebabkan penyakit pada hewan atau manusia (www.who.int, 2020). COVID-19 paling utama ditransmisikan oleh tetesan aerosol penderita dan melalui kontak langsung 
(Safrizal, 2020). Rekomendasi standar untuk mencegah penyebaran infeksi adalah melalui cuci tangan secara teratur menggunakan sabun dan air bersih (Fathiyah, 2020). Sebagai langkah antisipasi penyebaran COVID-19 pemerintah Indonesia mengeluarkan kebijakan untuk melakukan segala kegiatan dari rumah.

Kondisi ini memberi dampak perubahan pada lembaga pendidikan formal, informal, dan nonformal dengan menutup pembelajaran tatap muka dan beralih dengan pembelajaran daring (online). Peralihan pembelajaran, dari yang semula tatap muka menjadi pembelajaran daring memunculkan banyak hambatan bagi guru, mengingat hal ini terjadi secara mendadak tanpa adanya persiapan sebelumnya. (Rigianti, 2020).

Sejak diumumkan oleh Presiden Joko Widodo mengenai kasus pertama Corona Virus Disease 2019 (COVID-19) pada awal Maret 2020 yang lalu, Indonesia kemudian dihadapkan pada masa pandemi. Hampir seluruh sektor kehidupan lumpuh, tidak terkecuali di bidang pendidikan (Keputusan 4 Menteri, 2020). Pandemi COVID-19 telah mengganggu proses pembelajaran secara konvensional (Sadikin, 2020).

Menurut Mendikbud Nadiem Makarim, 2020 (www.kemdikbud. go.id, 2020) mengungkapkan pendekatan belajar dari rumah sebagai langkah strategis pertama pemerintah dalam upaya pencegahan penyebaran Corona Virus Disease (COVID-19) secara luas. Kesehatan dan keselamatan para insan pendidikan menjadi prioritas pemerintah. Ia juga mengatakan bahwa pemanfaatan teknologi dapat diaplikasikan saat melakukan pembelajaran jarak jauh. Sehingga proses pembelajaran tetap dapat dilaksanakan dengan sesuai harapan. Guru sebagai tenaga pengajar dituntut untuk melakukan inovasi dalam pembelajaran dengan memanfaatkan aplikasi yang telah disediakan pemerintah untuk proses pendidikan. Misalnya saja aplikasi Rumah Belajar, Meja Kita, WeKiddo, hingga Google For Education. Pemerintah juga menyediakan alat konferensi video yang tersedia untuk seluruh pengguna G-Suite, dan Google Classroom, untuk mengikuti kelas dan melanjutkan pembelajaran jarak jauh dari rumah. (www.kemdikbud.go.id: 2020)

Berdasarkan wawancara yang peneliti lakukan dengan guru biologi di MAN 1 Medan, yang mana saat itu belum masuknya wabah COVID-19 di Indonesia. Peneliti mendapatkan informasi bahwa ketika pembelajaran tatap muka di dalam kelas guru biasanya menggunakan metode diskusi kelompok ataupun ceramah. Misalnya saja pada materi sistem pernapasan manusia, guru menggunakan model pembelajaran ceramah ataupun diskusi kelompok yang melibatkan siswa harus mempersentasikan hasil pembahasan kelompok di depan kelas. Selain itu guru juga memanfaatkan media pembelajaran berupa alat peraga dan Powerpoint yang dapat membantu siswa dalam menerima pembelajaran sehingga diharapkan dapat tercapainya tujuan dari proses pembelajaran yang diinginkan.

Selanjutnya, setelah berubahnya sistem pembelajaran tatap muka di kelas menjadi pembelajaran dari rumah dengan metode daring (online) sesuai dengan peraturan Kemendikbud tentang upaya pencegahan wabah corona virus maka MAN 1 Medan mengikuti peraturan dan pemerintah untuk melaksanakan proses belajar dirumah secara online. Melihat fakta tersebut maka guru dituntut untuk mempersiapkan metode pembelajaran dari rumah yang diharapkan mampu untuk memenuhi Kriteria Ketuntasan Minimal (KKM) siswa sehingga tujuan pembelajaran dapat tercapai sesuai dengan harapan. Untuk mengetahui bagaimana proses pembelajaran biologi secara online di MAN 1 Medan maka peneliti melakukan wawancara dengan salah satu guru biologi di MAN 1 Medan, ia mengatakan bahwa pada saat pembelajaran dilakukan secara online, pola pengajaran yang biasanya dilakukan di sekolah tidak dapat sepenuhnya dilakukan secara online. Ketika dilakukan pembelajaran secara online maka guru hanya mampu memberikan materi kepada siswa baik melalui tatap muka online ataupun 
pembelajaran E-Learning, ini menandakan bahwa kurangnya variasi model pembelajaran yang digunakan oleh guru pada saat proses pembelajaran daring berlangsung dikarenakan faktor komunikasi dan tatap muka secara online yang berlangsung terbatas. Adanya variasi dalam mengajar dilihat sebagai sesuatu yang energik, antusias, bersemangat, dan semuanya memiliki relevansi dengan hasil belajar. Artinya, keterampilan guru dalam mengadakan variasi memiliki keterkaitan dengan prestasi belajar (Artikawati, 2016).

Kegiatan pembelajaran online yang dilakukan oleh guru biologi MAN 1 Medan yaitu dengan memanfaatkan aplikasi berupa google meet dan google classroom sebagai aplikasi pembelajaran tatap muka secara online. Lalu untuk pemberian soal berupa tugas ataupun ulangan menggunakan fasilitas berupa $E$ Learning ataupun aplikasi Whatsapp. Penggunaan media sosial sebagai sarana pembelajaran daring akan mengurangi dampak negatif media sosial yang selama ini banyak dikeluhkan oleh berbagai kalangan (Kuntarto, 2017). E-Learning merupakan media pembelajaran yang dapay digunakan untuk membantu proses belajar mengajar (Nuri Aslami, 2020).

Berdasarkan fakta tersebut, maka peneliti tertarik untuk melakukan sebuah penelitian yang membahas tentang bagaimanakah efektivitas dari proses pembelajaran biologi di masa pandemi yang dikemas dalam penelitian berjudul Efektivitas Pembelajaran Biologi pada Masa Pandemi COVID-19 di MAN 1 Medan.

Rumusan penelitian ini adalah apa saja faktor pendukung dan penghambat proses pembelajaran biologi pada masa pandemi COVID-19 di MAN 1 Medan serta bagaimanakah tingkat efektivitas pembelajaran biologi pada masa pandemi COVID-19 di MAN 1 Medan.

Tujuan dari penelitian ini adalah untuk mengetahui faktor pendukung dan penghambat pembelajaran biologi pada masa pandemi COVID-19 di MAN 1 Medan. Serta untuk melihat efektivitas dari pembelajaran biologi pada masa pandemi COVID-19 di MAN 1 Medan.

\section{METODE}

Pada penelitian ini peneliti menggunakan jenis penelitian deskriptif kualitatif berupa studi kasus, hal ini dikarenakan segala aspek pengambilan data tidak luput dari perhatian dan perlu penguraian yang rinci dan sistematis.

Teknik pengumpulan data pada penelitian ini menggunakan wawancara, observasi, kuesioner, dan dokumentasi.

Adapun subjek dalam penelitian ini yaitu peserta didik MAN 1 Medan kelas X sebanyak 155 orang, kelas XI sebanyak 61 orang, dan kelas XII sebanyak 85 orang. Objek dalam penelitian ini adalah efektivitas pembelajaran biologi pada masa pandemi COVID-19 serta faktor-faktor pendukung dan penghambat pembelajaran biologi secara daring di MAN 1 Medan.

Penelitian dilakukan kurang lebih tiga minggu, sejak tanggal 03 Agustus 2020 sampai 20 Agustus 2020. Dalam penelitian ini peneliti mengambil lokasi penelitian di kawasan sekitar MAN 1 Medan.

Adapun metode analisis data yang digunakan yaitu reduksi data, penyajian data, dan pemberian kesimpulan. Pada penelitian ini peneliti juga menggunakan uji keabsahan data metode triangulasi yaitu berupa triangulasi waktu, triangulasi sumber, dan triangulasi teknik.

\section{HASIL DAN PEMBAHASAN}

Berdasarkan penelitian yang telah dilakukan di MAN 1 Medan, peneliti mendapatkan hasil bahwa, pada bagian pengelolaan belajar MAN 1 Medan menyiapkan jaringan internet yang memadai dilengkapi dengan 12 ruangan belajar bagi guru yang melaksanakan pembelajaran daring disertai dengan jadwal piket pembelajaran sesuai dengan bidang studi. Hal ini sesuai dengan aturan pemerintah melalui surat edaran No.15 Tahun 2020 tentang peran kepala satuan pendidikan dalam mengatur pengelolaan pembelajaran dari rumah serta memastikan bahwa sistem pembelajaran dapat terjangkau oleh peserta didik. (SE No.15 Tahun 2020, 2020). 
Pengelolaan kelas dalam meningkatkan belajar siswa dilakukan dengan membuat perencanaan dan melaksanakan perencanaan dengan nenerapkan prinsip dan pendekatann pengelolan kelas serta pengawasan dilakukan secara berkelanjutan dengan memperhatikan faktor pendukung dan penghambatnya (Warsono, 2016). Pengelolaan yang dilakukan berupa proses perencanaan, pengorganisasian, kepemimpinan dan pengendalian kegiatan sekolah sehingga tujuan pembelajaran dapat tercapai (Naway, 2016).

Selanjutnya dalam hal sistem pembelajaran MAN 1 Medan juga melaksanakan sistem belajar berbasis aplikasi yang dapat dijangkau oleh seluruh siswa dan sebelumnya telah disosialisasikan melalui wali kelas. Sistem belajar MAN 1 Medan dilakukan dengan berdasarkan roster pembelajaran secara daring yang diberikan oleh sekolah sehingga guru wajib memberikan pelajaran sesuai dengan roster. Pengelolaan yang dilakukan berupa proses perencanaan, pengorganisasian, kepemimpinan dan pengendalian kegiatan sekolah sehingga tujuan pembelajaran dapat tercapai. Sehingga diharapkan dengan adanya perencanaan efektivitas dan efisiensi dalam mencapai tujuan belajar dapat tercapai. (Farida Jaya, 2019).

Pada bagian rencana keberlanjutan pembelajaran, sebagai suatu proses mempersiapkan hal-hal yang akan datang (Rusydi Ananda, 2019), MAN 1 Medan telah mempersiapkan beberapa rencana kedepannya apabila pandemi berlangsung dalam kurun waktu lama kedepannya. Rencana yang dipersiapkan misalnya pembelajaran dengan sistem gelombang dimana peserta didik tetap hadir ke sekolah namun tidak setiap hari hanya beberapa hari dalam seminggu dan kurun waktu yang lebih singkat. Namun dikarenakan belum disahkannya peraturan pemerintah Kementerian Agama tentang pembelajaran sistem gelombang maka MAN 1 Medan tetap memberlakukan pembelajaran daring dengan memonitori guru dan siswa secara teratur. Hal ini berkaitan dengan kurikulum yang berlaku sebagai rencana pembelajaran. (Sri Hayati, 2017)

Pembinaan belajar yang dilakukan MAN 1 Medan dengan cara memberlakukan absensi secara terpadu kepada guru dan juga membuat pelatihan tentang pembelajaran jarak jauh. Setiap minggunya guru juga diminta untuk mengumpulkan RPP yang telah diajarkan kepada siswa untuk memantau guru dan siswa dalam melaksanakan pembelajaran. Sehingga dengan adanya RPP pembelajaran dapat berlangsung sistematis. (Farida Jaya: 2019)

Pembelajaran yang dilakukan secara jarak jauh juga membutuhkan sarana dan prasarana yang memadai agar pembelajaran dapat bejalan dengan lancer. Sarana dan Prasarana merupakan kelengkapan dan fasilitas dalam melaksanakan proses belajar (Nurdyansyah, 2016). Sekolah mempersiapkan ruangan belajar untuk para guru sesuai dengan MGMP bidang studi. Hal ini dikarenakan guru dibebaskan untuk datang kesekolah namun tetap harus memenuhi protokol kesehatan COVID-19. Sekolah juga menyediakan headset yang dipinjamkan sementara kepada guru milik laboratorium komputer untuk memudahkan guru dalam berkomunikasi dengan siswa.

Pembelajaran adalah proses interaksi peserta didik dengan pendidik dan sumber belajar pada suatu lingkungan belajar (Hasan, 2017). Model pembelajaran interaktif dapat dipahami sebagai pembelajaran yang menekankan pada komunikasi antar siswa maupun siswa dengan guru melalui interaksi langsung dengan sumber belajar. (Widiantono, 2017)

Pada pelaksanaan pembelajaran sekolah juga tetap berkomunikasi dengan para orang tua murid melalui wali kelas dalam hal saling bekerjasama untuk melancarkan pelaksanaan pembelajaran daring. Wali kelas selaku pengganti orang tua yang mampu memberikan rasa nyaman dan mengayomi peserta didik (Amiruddin, 2017). Namun, tidak jarang wali kelas menerima kritikan dari orang tua tentang biaya sekolah yang tidak berkurang meskipun pembelajaran tidak dilakukan di sekolah hal ini 
sebenarnya sedang didiskusikan dengan kepala sekolah namun belum mendapatkan keputusan tentang bagaimana jalan keluarnya. Dalam pembelajaran daring ini MAN 1 Medan juga membentuk tim siaga COVID-19 yang beranggotakan para guru secara berkelompok sebagai tim siaga COVID-19. MAN 1 Medan juga memiliki fasilitas westafel untuk membersihkan tangan, termometer digital untuk mengecek suhu tubuh, dan wajib masker bagi siapapun yang berkunjung ke wilayah MAN 1 Medan.

MAN 1 Medan juga terus berkomunikasi dengan Dinas Pendidikan dan Kementerian Agama dalam hal melaporkan sejauh mana pembelajaran dari rumah dilaksanakan dan seperti apa kendala yang ditemukan lalu bagaimana solusinya. Kendala yang ditemukan berupa proses pembelajaran belum dilaksanakan secara optimal hal ini dikarenakan terbatasnya ruang lingkup komunikasi guru dan siswa. Selain itu sinyal dan jaringan juga sangat berpengaruh dalam pelaksanaan pembelajaran daring. Namun kendala ini dapat diatasi dengan baik dan tidak menghambat pembelajaran sehingga pembelajaran dapat dilaksanakan dengan baik sebagaimana biasanya.

Pelaksanaan pembelajaran biologi secara daring di MAN 1 Medan telah terlaksana dengan baik, misalnya saja dalam hal rencana pelaksanaan pembelajaran. RPP daring pembelajaran biologi telah dibuat oleh guru MAN 1 Medan. RPP tersebut berbentuk sederhana yang habis untuk satu kali pertemuan. Selain itu proses pembelajaran juga berjalan dengan baik sehingga tujuan belajar dapat tercapai namun belum optimal dikarenakan model pembelajaran yang diberikan guru cenderung monoton dan hanya diskusi sehingga kurangnya variasi dalam belajar.

Selanjutnya guru dituntut untuk melakukan proses pengajaran. Dalam hal ini mengajar adalah pemberian bimbingan kepada siswa untuk belajar atau menciptakan lingkungan atau kemudahan bagi siswa untuk melakukan kegiatan belajar (Syafaruddin, 2019). Selain mengajar guru juga memberikan motivasi dalam belajar. Pada saat observasi saya melihat motivasi diberikan kepada siswa dalam bentuk nasehat akan pentingnya kesehatan dan kedisiplinan waktu. Guru juga memberikan motivasi kepada siswa secara online dengan cara memberikan hiburan saat belajar dan mengingatkan siswa untuk menjaga kesehatan. Guru harus berupaya secara maksimal agar siswa termotivasi untuk belajar. Oleh karena itu motivasi belajar menjadi salah satu kunci keberhasilan dalam mencapai tujuan pembelajaran. (Emda, 2017)

Penilaian hasil belajar ini harus memenuhi prinsip sebagaimana diungkapkan oleh Anderson, 2003 (dalam Abi, 2016) yaitu (1) bermakna (meaningfulness), siapa pun yang berkepentingan terhadap hasil penilaian siswa dapat melihat makna di balik hasil penilaian yang telah dilakukan tersebut, (2) transparansi atau keterbukaan setiap pihak yang membutuhkan informasi hasil belajar siswa dapat mengetahui bagaimana guru melakukan kegiatan penilaian belajar siswa dan hasil penilaiannya. Penilaian yang diberikan guru biologi tidak hanya mengutamakan nilai angka melainkan berdasarkan afektif dan psikomotorik siswa. Guru menilai berdasarkan kehadiran dan kedisiplinan siswa dalam mengumpulkan tugas. Guru juga memberikan nilai lebih bagi siswa yang aktif dalam bertanya dan menjawab pertanyaan guru selama pembelajaran berlangsung.

Metode interaksi guru dan murid dilaksanakan secara daring yang mana sangat bergantung pada teknologi ataupun jaringan. Teknologi dapat meningkatkan kualitas dan jangkauan apabila digunakan secara bijak untuk pendidikan dan latihan, dan mempunyai arti yang sangat penting bagi kesejahteraan (Budiman, 2017). Ini juga merupakan salah satu kendala yang dialami. Kendala dalam pelajaran misalnya saja kehadiran siswa yang terlalu sedikit saat pertemuan online sehingga pembelajaran kurang efektif selain itu dengaan terbatasnya ruang dan waktu membuat keterbatasan dalam mengajar. Sehingga berdampak kepada siswa yang memperoleh 
pembelajaran tidak keseluruhan namun kendala tersebut tetap selalu diusahakan agar dapat diatasi dengan baik.

Media pembelajaran sebagai sumber belajar merupakan suatu komponen system pembelajaran yang meliputi pesan, orang, bahan, alat, teknik, dan lingkungan, yang dapat mempengaruhi hasil belajar peserta didik (Cahyadi, 2019). Media pembelajaran yang bersifat interaktif dan menarik dapat memberikan pembelajaran yang bersifat nyata serta menarik perhatian dan minat dari peserta didik (Sulastri, 2017). Media pembelajaran biologi yang digunakan oleh guru MAN 1 Medan pada dasarnya adalah powerpoint. Namun dilengkapi juga dengan buku ajar siswa dan terkadang guru memberikan video pembelajaran sesuai dengan materi biologi yang diajarkan. Guru MAN 1 Medan juga diberikan pelatihan dalam rangka meningkatkan kualitas guru khususnya dalam hal pembelajaran daring. Pelatihan yang dilakukan seperti pelatihan menggunakan Google Meet, Google Class Room, dan E-Learning. Guru juga memanfaatkan aplikasi whatsapp grup untuk terhubung dengan seluruh siswa. Dalam batas tertentu, media dapat menggantikan fungsi guru sebagai sumber informasi atau pengetahuan bagi peserta didik. Media pembelajaran sebagai sumber belajar merupakan suatu komponen system pembelajaran yang meliputi pesan, orang, bahan, alat, teknik, dan lingkungan, yang dapat mempengaruhi hasil belajar peserta didik.

Selanjutnya adalah partisipasi belajar atau dalam bahasa sederhana di sebut keikutsertaan seseorang dalam belajar. Partisipasi tersebut diukur dari seberapa besar keterlibatan anggota dalam aktivitas-aktivitas kelompok. (Fatmawati, 2019). Pada penelitian ini partisipasi belajar dilakukan dengan tatap muka virtual. Pertemuan tatap muka virtual yang dilakukan guru dan siswa tidak dilakukan di setiap pertemuan pembelajaran biologi. Namun, dalam pembelajaran Bab baru ataupun materi baru guru akan melakukan pertemuan online dengan aplikasi google meet. Hal ini dikarenakan untuk menghemat kuota internet siswa dalam mengakses pembelajaran. Virtual classroom (kelas maya) akan membawa situasi kelas nyata ke dalam teknologi dan mengubah situasi belajar mengajar tesebut seolah-olah menjadi nyata (Wachid, 2018).

Berdasarkan pembahasan di atas dapat diketahui bahwa langkah-langkah yang harus dilakukan oleh kepala satuan pembelajaran selama pembelajaran jarak jauh $88 \quad \%$ terlaksana dengan baik di MAN 1 Medan sesuai dengan surat edaran pemerintah No. 15 tahun 2020. Selanjutnya berdasarkan langkah-langkah yang harus dilakukan oleh guru khusunya guru biologi dalam pelaksanaan belajar jarak jauh sebanyak $75 \%$ terlaksana dengan baik sesuai dengan surat edaran pemerintah No. 15 tahun 2020.

Maka dari itu, dapat diketahui bahwa tingkat efektivitas pelaksanaan pembelajaran dari rumah pada mata pelajaran biologi yang dilakukan di MAN 1 Medan sebanyak $82 \%$ berjalan dengan efektif sesuai dengan aturan pemerintah melalui Surat Edaran No.15 Tahun 2020. Tentang langkah-langkah yang harus dilakukan oleh kepala satuan pendidikan dan guru dalam menjalankan pembelajaran dari rumah pada masa pandemi COVID-19.

Namun, berbeda hal nya dengan penelitian yang dilakukan oleh Lukman Feri dan Andi Sahtiani Jahrir tentang Efektivitas Pembelajaran Daring di Tengah Pandemi COVID-19 pada Universitas Negeri Makassar memperoleh hasil yang kurang efisien disebabkan kurangnya faktor pendukung seperti biaya, waktu, dan jaringan yang kurang stabil.

Sebaliknya pada penelitian yang dilakukan oleh Nety Fitriani tentang Efektivitas Pembelajaran Daring pada Masa Pandemi COVID-19 di SMK Negeri 1 Cirebon memperoleh hasil bahwa pelaksanaan pembelajaran daring berjalan efisien karena sarana dan prasarana yang disediakan cukup memadai. Namun perlu adanya metode pembelajaran atau penggunaan media yang inovatif agar siswa dapat memahami penyampaian materi oleh guru. 


\section{PENUTUP}

Faktor penghambat pembelajaran dari rumah pada mata pelajaran biologi di MAN 1 Medan adalah kondisi jaringan yang tidak stabil, adanya siswa yang tidak hadir dalam pelaksanaan pembelajaran biologi secara daring, kondisi ekonomi siswa, serta tidak seluruhnya siswa memiliki gadget ataupun laptop.

Faktor yang mendukung pembelajaran dari rumah pada mata pelajaran biologi di MAN 1 Medan adalah teknologi yang dimanfaatkan dengan menggunakan jaringan internet, tempat belajar yang difasilitasi, sumber belajar dan media belajar yang memadai, RPP yang dirancang oleh guru, sikap antusias dan rasa tanggung jawab siswa dalam menuntut ilmu, dan sarana prasarana yang memadai.

Tingkat efektivitas pembelajaran biologi pada masa pandemi COVID-19 di MAN 1 Medan sebanyak $82 \%$ berjalan efektif sesuai dengan aturan pemerintah melalui Surat Edaran No.15 Tahun 2020. Tentang langkah-langkah yang harus dilakukan oleh kepala satuan pendidikan dan guru dalam menjalankan pembelajaran dari rumah pada masa pandemi COVID-19.

\section{REFERENSI}

Abi, Mustofa Hamid. (2016). Pengembangan Instrumen Penilaian Hasil Belajar Siswa Berbasis Tik Pada Pembelajaran Dasar Listrik Elektronika. Jurnal Ilmiah Pendidikan Teknik Elektro, 1(1), 37-46.

Ananda, Rusydi. (2019). Perencanaan Pembelajaran. Medan: LPPI.

Artikawati, Rinta. (2016). Pengaruh Keterampilan Mengadakan Variasi Terhadap Prestasi Belajar Siswa Kelas IV SD. Jurnal Pendidikan Guru Sekolah Dasar, 5(11).

Aslami, Nuri. (2020). Potensi E-Learning Melalui Sistem Kuliah Online dalam Meningkatkan Mutu Pembelajaran Prodi Manajemen. Skripsi. Medan: UIN Sumatera Utara.
Budiman, Haris. (2017). Peran Teknologi Informasi dan Komunikasi dalam Pendidikan. Jurnal Pendidikan Islam, 8(1).

Cahyadi, Ani. (2019). Pengembangan Media dan Sumber Belajar. Banjarmasin: Laksita Indonesia.

Emda, Amda. (2017). Kedudukan Motivasi Belajar Siswa dalam Pembelajaran. Jurnal Lantanida. 5(2), 93-196.

Fatmawati, Soraya. (2019). Efektivitas Forum Diskusi pada E-Learning Berbasis Moodle untuk Meningkatkan Partisipasi Belajar. Jurnal Ilmiah dan Kependidikan, 9(2), 211216.

Feri, Lukman dan Andi Sahtiani. (2020). Efektivitas Pembelajaran Daring di Tengah Pendemi Covid-19. Skripsi. Pendidikan Bahasa dan Sastra: Makassar.

Fitriani, Nety. (2020). Efektivitas Pembelajaran Daring Selama Pandemi Covid-19. Thesis. Pendidikan Teknik Elektro. Universitas Pendidikan Indonesia: Bandung.

Jaya, Farida (2019). Perencanaan Pembelajaran, Medan: UINSU.

Fathiyah Isbaniah, et.al. (2020). Pedoman Pencegahan dan Pengendalian Corona Virus Disease (Covid-19). Jakarta: Kementerian Kesehatan RI.

Hayati, Sri. (2016). Belajar dan Pembelajaran Kooperatif Learning. Magelang: Graha Cendekia.

KEMENDIKBUD RI. "Darurat Covid-19, Mendikbud: Kesehatan Pelaku Pendidikan Jadi Prioritas Utama Pemerintah", https//: kemdikbud.go.id, Diakses pada tanggal 20 Juli 2020.

Keputusan Bersama 4 Menteri, Panduan Penyelenggaraan Pembelajaran. Jakarta: Kemdikbud.

Kuntarto, Eko. (2017). Keefektifan Model Pembelajaran Daring dalam Perkuliahan Bahasa Indonesia di Perguruan Tinggi. Journal Indonesian Language and Literature, 3(1). 

Jurnal Biolokus: Jurnal Penelitian Pendidikan Biologi Dan Biologi Vol.3 (2)

Naway, Fory.A. (2016). Strategi Pengelolaan Pembelajaran. Gorontalo: Ideas Publishing.

Nurdyansyah dan Eni Fahyuni. (2016). Inovasi Model Pembelajaran, Sidoarjo: Nizamia Learning Center.

Rigianti, Henry Aditya. (2020). Kendala Pembelajaran Daring Guru Sekolah Dasar di Kabupaten Banjar Negara. Jurnal Pendidikan, $7(2)$.

Rohani. (2019). Media Pembelajaran. Medan: UINSU.

Sadikin, Ali dan Hamidah, A. (2020). Pembelajaran Daring pada Masa Pendemi Covid-19. Jambi: Universitas Jambi.

Safrizal et.al, (2020). Pedoman Menghadapi Pandemi Covid-19 Bagi Pemerintah Daerah, Jakarta: Tim Kerja Menteri Dalam Negeri.

Siahaan, Amiruddin dan Hidayat, R.. (2017). Konsep-Konsep Keguruan dalam Pendidikan Islam. Medan: LPPI.

Sulastri. (2017). Efektivitas Penggunaan Media Powerpoint dalam Pembelajaran PAI di SMP Tunas Dharma Way Galih Lampung Selatan Tahun Ajaran 2016/2017. Skripsi. Lampung: IAIN Raden Intan.
Syafaruddin. (2019). Manajemen dan Strategi Pembelajaran. Medan: Perdana Publishing.

Usiono. (2016). Pancasila dan Kewarganegaraan. Medan: Perdana Publishing.

Wachid, Nuur Abdulmajid dan Rochmah, E. (2018). Membangun virtual classroom melalui social learning networks (SLNS). Jurnal Pendidikan Dasar dan Pembelajaran, 8(1), 15-21.

Warsono, Sri. (2016). Pengelolaan Kelas dalam Meningkatkan Hasil Belajar Siswa. Jurnal Manajer Pendidikan, 10(5), 469-476.

Widiantono, Nugroho dan Harjono, N. (2017). Penerapan Model Pembelajaran Interaktif Untuk Meningkatkan Aktivitas dan Hasil Belajar Ipa Siswa Kelas 5 SD. Jurnal Pendidikan dan Kebudayaan, 7(3), 199-213.

World Health Organization, "Pertanyaan dan Jawaban Terkait Corona Virus", www. who.int. Diakses pada tanggal 20 Juli 2020. 